\title{
Autistic children and adolescents and their parents: being and having meals together
}

\author{
Crianças e adolescentes autistas \\ e seus pais: o estar e \\ comer juntos
}

Bruna Muratti Ferraz de OLIVEIRA 1 iD 0000-0002-1669-8453
Maria Fernanda Petroli FRUTUOSO² ID $0000-0002-6078-5511$

\section{A B S T R A C T}

\section{Objective}

This study analyzed collective activities, involving eating with autistic children and adolescents, their families and professionals and included walks to street-food markets, picnics and participating in Festa Junina, aiming at investigating feeding in the perspective of commensality.

\section{Methods}

Ethnographic research carried out, based on participant observation during a walk to the street-food market, picnic and Festa Junina, conducted with 19 children and 13 adolescents of an Institution for autistic people. The data recorded were analyzed within the phenomenology framework.

\section{Results}

The activities showed the interaction of autistic children/adolescents with space, people and food, revealing the way autistic people relate, belong and position themselves. The investigators highlighted commensality, emphasizing food as a mediator of relationships, considering a scenario that may present contradictions and power relationships, and allows new possibilities of being together with this audience, outside home and beyond therapeutic care.

1 Centro Estadual de Educação Tecnológica Paula Souza, Escola Técnica Estadual Sales Gomes, Curso de Nutrição e Dietética. Praça Adelaide Barnsley Guedes, n.1, Centro, 18270-020, Tatuí, SP, Brasil. Correspondence to: B.M.F. OLIVEIRA. E-mail: <olivebmf@gmail.com>.

2 Universidade Federal de São Paulo, Instituto Saúde e Sociedade, Departamento de Políticas Públicas e Saúde Coletiva. Santos, SP, Brasil.

Article elaborated from the dissertation by B.M.F. OLIVEIRA, entitled "Muito além dos nutrientes: a dinâmica alimentar de crianças autistas". Universidade Federal de São Paulo; 2018.

How to cite this article

Oliveira BMF, Frutuoso MFP. Autistic children and adolescents and their parents: being and having meals together. Rev Nutr. 2021;34:e200254. https://doi.org/10.1590/1678-9865202134200254 


\section{Conclusion}

Staying and eating in a group influences the autistic child/adolescent and the activities were configured as an invitation to shared meals, with unexpected behaviors that went beyond institutional therapeutic purposes.

Key words: Adolescent. Autism Spectrum Disorder. Child. Feeding. Parents.

\section{RE S U M O}

\section{Objetivo}

Este estudo analisou as atividades coletivas envolvendo o comer com crianças e adolescentes autistas, familiares e profissionais (passeio à feira livre, piquenique e Festa Junina), com vistas a explorar a alimentação na perspectiva da comensalidade.

\section{Métodos}

Pesquisa etnográfica, a partir da observação participante de um passeio à feira livre, piquenique e Festa Junina, realizados com 19 crianças e 13 adolescentes em Instituição que atende autistas. Os dados produzidos foram analisados segundo referencial da fenomenologia.

\section{Resultados}

As atividades evidenciaram a interação da criançaladolescente autista com o espaço, pessoas e alimentos, apontando formas de se relacionar, pertencer e se posicionar. Destacaram a comensalidade, enfatizando o alimento como mediador das relações, a partir de um cenário que pode apresentar contradições e relações de poder, e permitiram novas possibilidades de ser e estar junto a este público, para além dos cuidados domiciliares e terapêuticos.

\section{Conclusão}

O estar e comer em grupo influenciam a alimentação da criança/adolescente autista e as atividades configuraram-se em um convite às refeições compartilhadas, com comportamentos inesperados e que vão além dos propósitos terapêuticos institucionais.

Palavras-chave: Adolescente. Transtorno do Espectro Autista. Criança. Alimentação. Pais.

\section{N TROD U C T I O N}

Starting with birth, the child receives different stimuli, establishing a complex relationship with the world, including feeding. According to the recommendations for children under 2 years of age, organizing a setting in which they can choose food, have experiences and sensations and having meals together with the family, encourages autonomy and contributes to a healthy relationship with food [1].

The current recommendations of the Food Guide for the Brazilian Population value the act of eating, regular and attentive, in an appropriate environment and with other people - commensality [2]. In this connection, considering the socio-anthropological perspective of food, commensality is understood as an expressive manifestation of human sociability, with moments that can have a positive impact on well-being and family union. It encompasses, therefore, how one eats, in addition to what one eats [3].

However, family meals are not always quiet moments, with behaviors considered socially correct and of social interaction, and these issues have more unique outlines in autistic children, when caregivers report challenges and concerns at mealtime [4].

Mothers describe these occasions as "stressful", "chaotic" and "exhausting", and state that, in most cases, their autistic children's meals are taken separately from their families [5]. The challenges reported include the difficulty in keeping children seated at the table, selectivity - limited food consumption and food monotony, resulting in concerns about inadequate nutrient intake and child development [4]. 
These aspects can be expanded by the production of knowledge about autistic nutrition. One of the lines of investigation suggests that a different intestinal biology jeopardizes the body's metabolic processes [6]. This line of thought directs dietary interventions that may produce potential behavioral improvements; they include gluten and casein restriction and supplementation of prebiotics, probiotics, omega 3 and 6 fatty acids, and multivitamins $[7,8]$. These findings are not consensual, but they encourage professional behaviors restricted to the physiological aspects of feeding, which can enhance the parents' concern with feeding their autistic children [7-9].

Considering the role of parents and family members in infant feeding, concerns about diet and difficulties at meal times of autistic children, this study investigated the interaction that these children establish with food and eating, in shared moments, based on the multidimensional understanding of food, and aimed to review collective activities involving food, with autistic children and adolescents and their families, and explore the perspective of commensality.

\section{METHODS}

This is an ethnographic research, approved by the Research Ethics Committee (opinion number $1,867,143$ of 12/14/2016), based on participant observation of institutional activities with autistic children and adolescents, shared with parents, family members and professionals, involving food and eating. A program was developed that included participants and activities, objectives, organization, dynamics and interactions of the actors with the itinerary/environment, with the food and also between them.

Participant observation is based on the assumption that the researcher penetrates the universe of those surveyed, in times of exchange, being both participant and observer of the individuals under study [9]. This relationship expands continuously, as both develop experiences in a given context, allowing to look at what is implicit [10].

The study was carried out in a non-profit Association in the interior of the State of São Paulo, founded in the 1990s, which offers interdisciplinary educational and therapeutic care for autistic persons and their families.

The study included 19 children and 13 adolescents, aged between 3 and 15 years of age, and their parents/relatives. These children/teenagers are assisted in the Association after school, and perform individual and/or group activities. Generally, mothers accompany them, waiting in a reserved place at the Association, and they participate, once a week, in activities guardian-oriented during this period of time.

In this research, children/adolescents and parents/relatives participated in three activities involving food intake: visit to the street food market, picnic and Festa Junina, with the presence of a Nutritionist, Occupational Therapist (OT), Educational Psychologist and Trainees (OT and pedagogy). The Psychologist, the Physiotherapist and the Dance Teacher also participated in the picnic, and, in the Festa Junina, the social worker and the music teacher were also present. These professionals had had daily contact with children/ adolescents for at least 6 months.

The children/adolescents formed a heterogeneous group with verbal interaction, pronunciation of sounds (without forming syllables/words), echolalia (repetition of sounds and speech) and without verbal communication.

As to food intake, an adolescent was diagnosed with food allergy and was on a diet indicated by an external professional. The parents/family members' reports about their children's feeding habits were diverse: food refusals and food selectivity; excessive food consumption; quiet meals, taken at the table with family members; children eating in a separate place from the family. 
The description of the activities was registered in diaries which, according to Mendes [11], constitute the writing of how the experience was perceived, with the joys and anxieties, uncertainties and contradictions to give visibility to the experienced events.

The records were reviewed according to the phenomenology framework, which consists in the description of the actual experiences and the meanings it has for the subjects who live through it [12]. In the field of food intake, this method allows us to understand the subjective and sociocultural senses and meanings of the act of eating [13].

Thus, the analysis of the diaries included an exhaustive reading of the material; the definition of units of meaning and the expression of the units and the formulation of a synthesis [12], with the selection of excerpts that illustrated the following analytical categories defined in the analysis: (1). Experiences and experiments with food; (2). Interaction of children/teenagers with people and the environment, based on commensality. Fictitious names were used for the participants, followed by the information on their age.

\section{RES U L T S}

The trip to the street-food market aimed to promote autistic child/adolescent autonomy in new places and extramural experiences with food. It was held in the morning, with two groups (A: 3 participants, between 7 and 12 years old and B: 5 participants, between 4 and 7 years old) and the presence of mothers. Before the visit, euphoria was noticed among the children/adolescents, some of them moved quickly towards the exit of the Association, such as Pedro (7 years old) who "[...] was excited, held his mother's hand and seemed to push her towards the exit".

In a $600 \mathrm{~m}$ walking, you can work on the notion of space and colors (traffic lights). At the street-food market, the psychopedagogist presented the stands and food to everyone, and the street market attendants interacted with the children: "When passing by a stand, the psychopedagogist asked João (9 years old) what was written on the sign and he replied "papaia". Immediately he was praised by the street market attendant".

Everyone sat at the fried pastry stand, the mothers arranged for the purchase of food and the professionals helped the entire process: "When we put the food on the table, João (9 years old) asked his mother to take away the vinaigrette dressing. He ate all the fried pastry, sipped the drink and asked Pedro (7 years old) if his food tasted good".

"Lucas' mother (4 years old) offered the drink and unfilled mini fried pastries to her son, who didn't show any interest. The intern drove a pastry to Lucas' mouth, who screamed and turned his face away. After a while, he started eating pastries and clapping the back of his hand".

"Caio (7 years old) calmly ate fried pastries. Upon leaving the Association, his grandfather had commented that Caio would never eat any pastries".

At his mother's request, João (9 years old) thanked the stand's attending person who was serving by saying "Thank you very much", and Paulo (9 years old) interacted with the food in a stand: "Paulo (9 years old) took a section of tangerine for tasting and bit into it. I asked him if he had liked it; he shook his head signaling "yes" and went to the Association with the tangerine section in his hand".

The picnic took place in the Association's yard, with two groups: (A): 6 participants, between 3 and 11 years old and (B): 4 participants, between 3 and 15 years old; to promote a commensality encounter. On the floor, colorful tatami mats were placed so that the participants could sit in a circle, with a towel in the center for the food brought by the families (snacks, chocolate cake, juices, cracknels, popcorn, sweets, among others): 
"Bruno (3 years old), with his mother, ate "dulce de leche", laughed and interacted with his brother who always accompanied him".

"Lucas (4 years old) and Vitor (7 years old) played catch-up with the psychologist; José (7 years old) sat quietly for a while, drank his drink and began walking barefoot on the mats in circles".

"Laura (11 years old) ate cracknels lying on the mat. She took off her socks, took the trainee's hands and drove them to her feet. The intern began to massage and Laura then pushed her hands to her other foot".

"The arrival of João (15 years old) and of his mother was celebrated by the professionals. João covered his ears with his hands and hid. His mother called him saying that cheesecakes had arrived. He entered the court and approached slowly".

"Mateus (12 years old) sat down, took the cookies out of the package, crumpled and ate a few pieces, sniffed and repeatedly uttered the commercial footing that was being broadcasted for a supermarket in the city".

The Festa Junina took place in the afternoon, at the Association, for all groups (32 children/teenagers) and was configured as a cultural event with dances, food and interactions. Families took the food that was placed on tables in the outdoor kiosk (juices, soft drinks, savory pies, couscous, roasted peanuts, cakes, hominy, rice pudding, chocolates, snacks and candies). There was a bouncy toy, a spinnaker and a cotton candy cart. All were characterized or wore some typical detail. A sound enlivened the party, with dance performances by children and mothers.

Some moments marked the interaction of children/adolescents with food and with the other participants:

"Eric (3 years old) asked for cotton candy, held the end of the stick and tried to touch the cotton. The trainee asked him if he was going to eat the cotton candy; he nodded and continued holding the cotton candy stick. The intern put some cotton in his mouth; he ate it and asked for more. He didn't touch the sugar cotton for a moment".

"Lucas (4 years old) was enjoying a candy. He licked all the chocolate and had chocolate smear all over his face. At this time Vitor (9 years old) approached and took the snack package next to Lucas. Lucas acted as if he would pull the package away preventing Vitor from taking it away, but his mother distracted him with another chocolate candy".

\section{DISCUSSION}

While walking and at the street-food market, the children/adolescents had a unique experience in the Association's external spaces, including interaction with an unfamiliar environment. The food exhibited and for sale at the stands was mostly fresh food. The fried pastry stand was the outstanding place selected because it was the place where people could sit.

Observation revealed the interaction of the autistic child/adolescent with space, people (mothers, professionals, salesmen, peers) and food, illustrating the ways these subjects positioned themselves and related with other people that can be opposed, to some extent, to the descriptions that enhance apathy and communication and socialization difficulties in Autism Spectrum Disorder (ASD).

Although the literature highlights social impairments caused by the disorder, focusing the relationship between the interactive contexts and children development requires that we consider 
that the involvement with the environment makes it possible to know, learn and reframe their position as individuals $[14,15]$.

The picnic was used as a group activity that took place in a known and restricted extramural space of the Association facilities, involving professionals, peers and family members. The observation detected different forms of interaction between children/adolescents and people/environment like playing, walking in a circle, hiding and relaxing.

The food was brought by the families, most of the time chosen according to the children/adolescents' preferences. The participants were distributed centrality around the food a positioning that allowed different forms of interaction like eating, touching, smelling, crumbling.

The sensory physiology of the autistic person is described scientifically as atypical and associated with food refusals and preferences (consistency, temperature, colors) and untoward behaviors at mealtimes $[16,17]$. These elements seemed to be present at the picnic, as well as the unique experiences that go beyond eating-nourishing. Feeling, sharing and eating, present in this activity, highlight the social role of food, as food was the mediator of interactions, enhancing the importance of commensality.

The Festa Junina was also held at the Association. All children/adolescents who moved between the different spaces and their families participated. Tables covered with white tablecloths accommodated food, which gained prominence at the kiosk. Standing, participants surrounded the tables and, between shouting, dancing, jumping, crying, talking and music, food was offered, disputed and consumed.

Food permeated these moments and, in addition to the nutritional focus, food and eating were considered in their sociocultural and commensality perspective. It should be noted that commensality, regardless of the presence of autistic individuals, is not always a pleasant and conflict-free time, as it expresses eating as a social act, with contradictions and power relationships [3].

The imbrication of biological, cultural and social aspects of feeding is marked from the beginning of childhood; as examples we have breastfeeding - nutritional offer and mother-child interaction - and the inclusion of the child in the family's eating practices. Food, therefore, is configured as the first social learning of human life [18]. In this sense, thinking about food and shared eating, in educational and care spaces, requires considering displacements, movements - learning [19].

Unusual autistic actions, such as those observed in these extramural activities (crying, wandering, licking, sniffing), open a field of discussion about their relationships. These children communicate, interact and live within a network, in which professional agents seek to achieve therapeutic objectives, the family members seek the development of the children's abilities and skills, and the child, with its uniqueness, develops this network, where everyone affects and is affected [20].

Multisensory experiences and shared eating with autistic children/adolescents are configured as spaces for socialization, exchange and connection, which make up this audience's food dynamics and show the complexity of eating processes taking into account unpredictable events [21].

It is interesting to highlight the participation of parents/guardians in the activities. The scientific literature that focused on impacts in the family dynamics caused by autistic individuals presented a scenario of abnegation, concern, dissatisfaction, overload, stress and loneliness, especially for mothers, in addition to the continuous struggle for the child's well-being [22-25].

By participating in the activities described above, family members played a leading role and mediated actions. They walked, talked, prepared, offered and consumed food, dressed typically and danced. They 
interacted with their children, parents/guardians, children and staff from new contexts, in addition to the usual ones (care at home).

In this connection, the potential of these proposals that were not limited to the achievement of therapeutic goals stand out, allowing for new possibilities of living and being with the autistic child/adolescent.

\section{CONCLUSION}

Living and eating in a group influence the diet of human beings and, for the autistic child/adolescent, it is no different. In the activities described, children/adolescents consumed and refused food, enjoyed sensory experiences, interacted with the spaces, their peers, staff and family members. They played, resisted, danced, cried. The participation of parents/guardians allowed new experiences with their children and other autistic children/adolescents, in activities that place commensality as an act that allows group interactions, with the environment and food.

Going to the street-food market, picnicking and partying are typical examples of activities for this audience that favor shared meals and make commensality a central feature, with a view to enhance the sociocultural aspects of food and allowing children to build connections mediated by food.

\section{CONTRIBUTORS}

All the authors contributed to the conception and design, analysis and interpretation of data, review and approval of the final version of the article.

\section{REFERENCES}

1. Ministério da Saúde (Brasil). Guia alimentar para crianças brasileiras menores de 2 anos. Brasília: Ministério; 2019.

2. Ministério da Saúde (Brasil). Guia alimentar para a população brasileira. Brasília: Ministério; 2014.

3. Oliveira MSS, Santos LAS. Guias alimentares para a população brasileira: uma análise a partir das dimensões culturais e sociais da alimentação. Ciênc Saúde Coletiva. 2020;25(7):2519-28. https://doi.org/10.1590/141381232020257.22322018

4. Chistol LT, Bandini LG, Must A, Phillips S, Cermak SA, Curtin C. Sensory sensitivity and food selectivity in children with autism spectrum disorder. J Autism Dev Disord. 2018;48(2):583-91. https://doi.org/ 10.1007/s10803-0173340-9

5. Lázaro CP, Pondé MP. Narratives of mothers of children with autism spectrum disorders: focus one ating behavior. Trends Psych Psychother. 2017;39(3):180-7. https://doi.org/10.1590/2237-6089-2017-0004

6. Ristori MV, Quagliariello A, Reddel S, laniro G, Vicari S, Gasbarrini A, et al. Autism, gastrointestinal symptoms and modulation of gut microbiota by nutritional interventions. Nutrients. 2019;18(11):2812. https://doi.org/10.3390/ nu11112812.

7. Millward C, Ferriter M, Calver SJ, Connell-Jone GG. Gluten-andcasein-free diets for autistic spectrum disorder. Cochrane Database Syst Rev. 2019;16(2):CD003498. https://doi.org/10.1002/14651858.CD003498.pub3

8. Keim SA, Gracious B, Boone KM, Klebanoff MA, Rogers LK, Rausch J, et al. $\omega-3$ and $\omega-9$ fatty acid supplementation may reduce autism symptoms based on parent report in preterm toddlers. J Nutr. 2018;148(2):227-35. https://doi. org/10.1093/jn/nxx047

9. Gogou M, Kolios G. Are therapeutic diets an emerging additional choice in autism spectrum disorder management? World J Pediatr. 2018;14(3):215-23. https://doi.org/10.1007/s12519-018-0164-4

10. Mónico LS, Alferes VR, Castro PA, Parreira PM. A observação participante enquanto metodologia de investigação qualitativa. CIAQ. 2017;3:724-33. 
11. Mendes R, Pezzato LM, Sacardo DP. Pesquisa-intervenção em promoção da saúde: desafios metodológicos de pesquisar "com". Ciênc Saúde Coletiva. 2016;21(6):1737-46. https://doi.org/10.1590/1413-81232015216.07392016

12. Moser A, Korstjens I. Series: practical guidance to qualitative research. Part 3: Sampling, data collection and analysis. Eur J Gen Pract. 2018;24(1):9-18. https://doi.org/10.1080/13814788.2017.1375091

13. Freitas MCS, Santos LAS. Sobre a fenomenologia do comer saudável no mundo da vida: breve ensaio. In: Freitas MCS, Silva DO. Narrativas sobre o comer no mundo da vida. Salvador: EDUFBA, 2014. p.33-40.

14. Kuchirko Y, Tafuro L, Tamis-Lemonda CS. Becoming a communicative partner: infant contingent responsiveness to maternal language and gestures. Infancy. 2017;23(4):558-76. https://doi.org/10.1111/infa.12222

15. Lemos ELMD, Nunes LL, Salomão NMR. Transtorno do espectro autista e interações escolares: sala de aula e pátio. Rev Bras Educ Espec. 2020;26(1):69-84. https://doi.org/10.1590/s1413-65382620000100005

16. Posar A, Visconti P. Sensory abnormalities in children with autism spectrum disorder. J Pediatr. 2018;94(4):342-50. https://doi.org/10.1016/j.jped.2017.08.008

17. Huxham L, Marais M, Van Niekerk E. Idiosyncratic food preferences of children with autism spectrum disorder in England. South Afr J Clin Nutr. 2019;1-7. https://doi.org/10.1080/16070658.2019.1697039

18. Polain, JP, Proença RPC. O espaço social alimentar: um instrumento para o estudo dos modelos alimentares. Rev Nutr. 2003;16(3):245-56. https://doi.org/10.1590/S1415-52732003000300002

19. Oliveira BMF, Frutuoso MFP. Muito além dos nutrientes: experiências e conexões com crianças autistas a partir do cozinhar e comer juntos. Cad Saúde Pública. 2021;37(4):e00132020. https://doi.org/10.1590/0102-311X00132020

20. Ferreira LBP. Um percurso sobre o autismo: história, clínica e perspectivas. Cad Deligny. 2018;1(1):110-9.

21. Oliveira BMF, Frutuoso MFP. Sem receita: deslocamentos do olhar da Nutrição sobre o comer de crianças autistas. Interface (Botucatu). 2020;24:e190597. https://doi.org/10.1590/Interface.190597

22. Pinto RNM, Torquato IMB, Collet N, Reichert APS, Souza Neto VL, Saraiva AM. Autismo infantil: impacto do diagnóstico e repercussões nas relações familiares. Rev. Gaúcha Enferm. 2016;37(3):e61572. https://doi.org/10.1590/19831447.2016.03.61572

23. Misquiatti ARN, Brito MC, Ferreira FTS, Assumpção Junior FB. Sobrecarga familiar e crianças com transtornos do espectro autismo: perspectiva dos cuidadores. Rev CEFAC. 2015;17(1):192-200. https://doi.org/10.1590/19820216201520413

24. Mohammadi F, Rakhshan M, Molazem Z, Gillespie M. Parental competence in parents of children with autism spectrum disorder: a systematic review. Invest Educ Enferm. 2019;37(3):e03. https://doi.org/10.17533/udea.iee. v37n3e03

25. Faro KCA, Santos RB, Bosa CA, Wagner A, Silva SSC. Autismo e mães com e sem estresse: análise da sobrecarga materna e do suporte familiar. Psico. 2019;50(2):e30080. https://doi.org/10.15448/1980-8623.2019.2.30080 